\title{
The role of a missional social entrepreneurial church in a township community
}

\begin{tabular}{|c|c|}
\hline $\begin{array}{l}\text { Author: } \\
\text { Semape J. Mar }\end{array}$ & yaka-Boshielo $^{1}$ (๑) \\
\hline $\begin{array}{l}\text { Affiliation: } \\
{ }^{1} \text { Department } \\
\text { Theology, Fac } \\
\text { and Religion, } \\
\text { Pretoria, Sout }\end{array}$ & $\begin{array}{l}\text { f Practical } \\
\text { Ity of Theology } \\
\text { Jniversity of } \\
\text { h Africa }\end{array}$ \\
\hline $\begin{array}{l}\text { Research Proj } \\
\text { Project Leade } \\
\text { Project Numb }\end{array}$ & $\begin{array}{l}\text { ect Details: } \\
\text { r: J.A. Meylahn } \\
\text { er: } 02187133\end{array}$ \\
\hline $\begin{array}{l}\text { Description: } \\
\text { Dr Manyaka-B } \\
\text { participating i } \\
\text { project, 'Towa } \\
\text { postfoundatio } \\
\text { public theolog } \\
\text { to the challen } \\
\text { religion in con } \\
\text { Southern Afri } \\
\text { Prof. Dr Johan } \\
\text { Department P } \\
\text { Theology, Fac } \\
\text { and Religion, } \\
\text { Pretoria. }\end{array}$ & $\begin{array}{l}\text { oshielo is } \\
n \text { the research } \\
\text { rds a practical } \\
\text { nal theology as } \\
y \text { in response } \\
\text { ges of lived } \\
\text { temporary } \\
\text { 'a', directed by } \\
\text { n Meylahn, } \\
\text { ractical } \\
\text { alty of Theology } \\
\text { Jniversity of }\end{array}$ \\
\hline $\begin{array}{l}\text { Correspondin } \\
\text { Semape Many } \\
\text { manyakasp@ }\end{array}$ & $\begin{array}{l}\text { g author: } \\
\text { aka-Boshielo, } \\
\text { smail.com }\end{array}$ \\
\hline $\begin{array}{l}\text { Dates: } \\
\text { Received: } 09 \text { | } \\
\text { Accepted: } 02 \\
\text { Published: } 13\end{array}$ & $\begin{array}{l}\text { eb. } 2018 \\
\text { lune } 2018 \\
\text { Sept. } 2018\end{array}$ \\
\hline $\begin{array}{l}\text { How to cite th } \\
\text { Manyaka-Bos } \\
\text { 'The role of a } \\
\text { entrepreneuri } \\
\text { township com } \\
\text { Teologiese Stu } \\
\text { Theological St } \\
\text { a4932. https:/ } \\
10.4102 / \text { hts.v }\end{array}$ & $\begin{array}{l}\text { is article: } \\
\text { nielo, S.J., 2018, } \\
\text { missional social } \\
\text { al church in a } \\
\text { munity', HTS } \\
\text { dies/ } \\
\text { udies 74(1), } \\
\text { /doi.org/ } \\
\text { 74i1.4932 }\end{array}$ \\
\hline $\begin{array}{l}\text { Copyright: } \\
\text { ( ) 2018. The } \\
\text { Licensee: AOS } \\
\text { is licensed un } \\
\text { Creative Com! } \\
\text { Attribution Lic }\end{array}$ & $\begin{array}{l}\text { ISthors. } \\
\text { IS. This work } \\
\text { der the } \\
\text { nons } \\
\text { ense. }\end{array}$ \\
\hline Read online: & \\
\hline 回战回 & $\begin{array}{l}\text { Scan this QR } \\
\text { code with your } \\
\text { smart phone or } \\
\text { mobile device } \\
\text { to read online. }\end{array}$ \\
\hline
\end{tabular}

This article explores the role of a missional social entrepreneurial church in the community. This kind of church exists in the community to be the light and the salt as stated in Matthew $5: 13,14$, which says, 'you are the salt of the earth ...' and 'you are the light of the world ...' These two metaphors might teach us more about the role of the church in all communities. The missional social entrepreneurial church has to play a role in bringing a holistic transformation in the world. Holistic transformation should affect the human spirit, mind, and emotional, physical, social, political and economic spheres as the word 'holistic' suggests. The church should influence the community in a comprehensive way. The author is convinced that if the church can play its role, then a holistic transformation is truly possible.

\section{Introduction}

The research project entitled 'Religious innovation and competition amidst urban social change: A Pretoria case study' has revealed many ills in the inner city and part of Mamelodi East where the research was carried out. The major ailment that has been realised is poverty, which is caused by high unemployment in the country; this has been confirmed by Statistics South Africa (Manyaka-Boshielo 2017b:1a; 2017b:1).

The co-researchers state that because of high unemployment the rate of crime is continually rising in their neighbourhoods. Teenage pregnancies are increasing in schools and in their communities. A sense of hopelessness and low self-esteem is everywhere. People lack a sense of self-worth and self-confidence.

This is a context in which the missional social entrepreneurial church should become the light and the salt. This kind of church can provide hope for those under the darkest cloud covering the township communities. In this article, the author intends to reflect on the steps that a missional social entrepreneur church would engage on in order to be the light and the salt for the community. Let us discuss to see how this church can be the light and the salt.

\section{Methodology}

This article is based on secondary data; this means that the author has used articles, books and the Internet to gather information. The primary data will be observational as the author is interacting in the township of Nellmapius in the North-East of Pretoria.

\section{Overview of township informal entrepreneurial activities}

Informal entrepreneurial activities are businesses that are not complying with the regulations of the South African government. The author observed many of these businesses. The following was observed in the inner city of Pretoria and Mamelodi East (Manyaka-Boshielo 2017a) and also in Nellmapius (Manyaka-Boshielo 2017b).

Charman et al. (2017) defined the informal economy as 'unregulated by the institutions of society, in a legal and social environment where similar activities are regulated'. Also, they demonstrate the role of an informal economy in the township as:

estimates hold that the country's informal economy provides at least 2.4 million people ( $13 \%$ of the labour force), whereas contributing toward the livelihood of 4.4 million unemployed and 14.9 million adults officially described as 'not economical'. (Charman et al. 2017:37)

These agree with the author's observation in Nellmapius. The following was observed before and during the writing of this article. 


\section{Rentals}

Driving through Nellmapius, one can also see as many as 10 tin shacks in one yard surrounding an RDP house (this is a house built by government for poor people in the township). Many people, especially foreign nationals, are renting those tin shacks. They pay around R1000.00 per room. Many people improve their rental business by buying RDP houses and then demolishing them to build proper modern rooms for rent and many of these rooms cost above R2500 per month. There is a substantial amount of money which is circulating through this kind of business and is not being accounted for tax purposes.

\section{Crèches and pre-schools}

There are many crèches in Nellmapius which do not comply with the city regulations. Money is being collected from the parents and not reported annually to the government as required by the law.

\section{Dipitseng}

Dipitseng means a place where someone uses a traditional three-legged black pot to cook bogobe le nama [porridge and meat or chicken] or more commonly known as pap and vleis. Every lunch time, you will see police vans and other cars stopping by them to buy food.

\section{Cakes}

They are ladies who sell cakes in many places in Nellmapius, particularly at the taxi ranks and the clinic. In fact, this is happening wherever there are many people. These ladies feed their families with the money they earn from their small businesses.

\section{Transport}

The taxi industry is one of the biggest businesses that originated in the townships. Many of these businesses do not comply with the regulations for public transport. Every morning one would see children being transported to school in different vehicles, many of which are unroadworthy.

The author can highlight many small businesses that are likely not to be registered with the relevant state departments. These people and some of their children can be considered professionals in the present day because of these informal businesses. The author is an example of being born in an extremely poor family. He sold fruit at Marabastad during the school holidays in order to fund his schooling. In addition to the informal entrepreneurial activities mentioned above, there are many entrepreneurial activities happening in the Nellmapius and Mamelodi communities. The author considers that this may be occurring through all townships. This is what motivated the author to carry out empirical research on informal business, to understand what is motivating this sector, the challenges faced by the informal businesspeople and why they are not registered.

The missional-entrepreneurial church can facilitate these informal businesses to be formalised so that they can receive financial assistance from government to grow their business and to comply with the South African Revenue Service (SARS) for tax purposes. This action will also help them to explore other market possibilities.

\section{Missional church}

We find missio Dei in Scripture: God the father sends the Son and the Spirit into the world, and God the father, Son and Spirit send the church into the world for the sake of the world (Woodward 2012:27). Carlson (2007), defined:

the missional church as an authentic community of faith that primarily directs its ministry focus outwards towards the context in which it is located and to the broader world beyond.

The missional church needs to focus towards those who live in darkness, to bring them to the light of God. The missional church exists to connect the people to the heart of God, to be reconciled.

The mission of God is fully expressed 'when God formed the world in which the crowning touch, human beings, became participants in creation's full development' (Van Gelder 2000:1, 2)

Woodward (2012:28) says God's mission is to redeem the world and restore it for its intended purpose. Christ sent his disciples to make disciples; Matthew 28:19-20 says:

therefore go and make disciples of all nations, baptizing them in the name of the father, and the Son, and the Holy Spirit, and teaching them to obey everything I have commanded you. And surely I am with you always, to the very end of the age.

Mark 16:15 says, 'He said to them, Go into the world and preach the gospel to all creation'. The church has been commissioned to preach the gospel to all the nations. Missional churches understood this mission and are acting on it.

Paul has this to say concerning God's mission (Eph 1:10), 'to put into effect when the times reach their fulfilment-to bring unity in heaven and on earth'. The missio Dei is to reconcile all of God's creation harmoniously. The church being the mission of God orientated towards working fully hand-inhand with God.

Missio Dei is centred on the cross of Jesus, resolving dualism, the tension and conflict between body and soul, evangelism and social action (Choi 2017:60).

\section{Social entrepreneurship}

It is essential to understand the meaning of 'social entrepreneurship' before we define a social entrepreneurial church. What is social entrepreneurship? Social entrepreneurship is a process of seeing the problem in the community (an unjust equilibrium), becoming alert to the opportunities that arise from the problem and devise and implement the systems and procedures for solving or, at least, addressing the problem (Manyaka 2015:4). 
Dees (1998:4) defined the entrepreneurial aspect of social entrepreneurship as (1) the recognition and relentless pursuit of new opportunities to further the mission of creating social value, (2) continuous engagement in innovation and modification and (3) bold action undertaken without acceptance of existing resource limitation.

Austin, Stevenson and Wei-Skillern (2006:2) highlighted that social entrepreneurship is an 'innovative social valuecreating activity that can occur within or across the nonprofit, profit making business and government sectors'.

Rey-Marti, Rebeiro and Palacios-Mangues (2016) defined social entrepreneurship as 'a process that creates innovative solutions to immediate social problems and mobilizes the idea, capacities, resources, and social agreements required for this sustainable social transformation'.

Social entrepreneurship is the ability of recognising the opportunity and innovatively and fearlessly acting on it. It is seeing a way where it seems there is no way.

\section{What is social entrepreneur?}

The social entrepreneur is a force behind the social entrepreneurship process. How can we define the social entrepreneur?

Bornstein (1998) defined Social Entrepreneur as a:

path-breaker with a powerful new idea, who combines visionary and real-world problem-solving creativity, who has a strong ethical fibre and who is totally possessed by his or her vision for change. (p. 37)

\section{Pippin (2001) stated that:}

authentic entrepreneurs have discovered that real security is not financial; it is when they tap into their inner power to live purposefully and create a meaningful lifestyle, not just a business. (pp. 1, 2)

The township community needs individuals who might be path-breakers, causing community transformation. This is a kind of a person who could be the light to shine in the darkness of poverty and unemployment, and the salt to give taste to the tasteless life of the poor. These are the people who are fully aware that the solution for their lives and the lives of their community is in their hands. They are the solution they want to see.

Social entrepreneurs have the unique ability to recognise the complex social problems and can work through them in a new way that raises public awareness of the problem through their vision, work and activity (Rahim and Mohtar 2015).

\section{Then what is social entrepreneurial church?}

This is the church that adds to her spiritual function for the community, the word and social entrepreneurial activities. A social entrepreneurial church helps the community to deal with the challenges that the community is facing, and to think about innovative possible solutions. As discussed above, social entrepreneurship involves social entrepreneurs and the recognition and relentless pursuit of new opportunities to further the mission of creating social value. Churchpreneurship engages in entrepreneurial activities as a way of overcoming poverty that has trapped the township communities and restoring human dignity.

This church engages in social entrepreneurial activities so that it can raise money to support its work and to empower members to play a role in adding value to the community. Indeed, the concept of entrepreneurial activities can be clearly seen in the Bible, in Genesis 1; we see God creating the universe, where he saw everything was created as good. God is seen as the Creator and the worker. It did not end there, as he continued his work through creating man in his image and likeness to partner with God in continuously shaping and reshaping the earth, for a better living. In Genesis 2:15NIV, the Bible says, 'the Lord God took the man and put him in the garden of Eden to work it and take care of it'. Psalm 8:6NIV says 'you made the rulers of the works of your hands'. Man was created by God to take charge of God's creation. The author opines that God had given him the necessary ability to continue recreating and improving. It means man is entrepreneurial and has the capacity to undertake new projects.

Paul, being the apostle who travelled throughout the world, was a social entrepreneur. He engaged in the tent-making trade to support his ministry of changing lives. Acts 18:3isv says 'and because they had the same trade he stayed with them. They worked together because they were tent-makers by trade'. In this Bible verse, we read that Paul was a tentmaker by trade. According to Oxford Advanced Learner's Dictionary, 'trade' means the activity of buying and selling, or exchanging of goods or services. This simply means that Paul was entrepreneurial. He is a social entrepreneur because his main aim was to support his mission work.

Entrepreneur refers to "someone who "undertakes"; not an undertaker in the sense of a funeral director, but someone who undertakes a significant project or activity' (Manyaka 2015:2). In addition to engaging in the trade of tent-making, Paul planted many churches, which were the projects he had undertaken; therefore, he could be said to be entrepreneurial. Those churches were social entrepreneurial projects to change the world.

According to Martin and Osberg (2007:30), entrepreneurship connotes 'a special, innate ability to sense and act on opportunity, combining out-of-the-box thinking with a unique brand of determination to create or bring about something new to the world'.

The medieval monasteries supported their missions through wineries and agriculture. Through these commercial ventures they were able to support their own needs and to feed the poor (Buttrick 1962:684). 
The society of Jesuits established mission-based business ventures to help in the funding of educational institutions. Moravians also ran enterprises to help with the work of the church to transform the world (Dodd \& Seaman 1998:74). The missionaries did not wait for Christians to fund them; they started social entrepreneurship organisations or businesses. These business ventures were focused on helping the heartfelt needs of poor people and to train indigenous people with skills and knowledge so that they might change their horrible conditions (Gonzalez 1984, Early Church 209).

Choi (2010:378) puts it this way: Korean churches are involved with business and community development issues directly and indirectly. Some churches and pastors hold formal programmes to inform their members of business opportunities. To take this further, they started a formal and informal organisation that could afford to offer loans to Koreans because the conventional banks are unable to offer Koreans loans.

Missional social entrepreneurial church exists to address the unemployment, brokenness, poverty and marginalisation of township communities by co-labouring with God to bring sustainable transformation through pattern-breaking ideas, through creativity of the Holy Spirit-empowered social entrepreneurs. Missional social entrepreneurial church is holistic in its approach in mission work. By being holistic this means it addresses spiritual, psychological, physical, social, emotional, economic and political aspects. By being holistic, it makes the church become the light and the salt of the earth. The light shines in the hopelessness of poverty and the salt adds flavour in hopelessness of the township communities.

\section{Breaking generational poverty}

The author was also born and bred in the poorest of the poor community, but thinks that entrepreneurial activities could be a solution to break this generational poverty in the township communities. Missional social entrepreneurial church as a social enterprise, founded by the pastor who could be known as social entrepreneur or pastorpreneur, could be the atmosphere for transformation.

Social pastorpreneurship causes social engineering by preaching and teaching the church members about the concepts and also encourages the members to rise and pick up their responsibilities in reshaping their destinies. The author also thinks that the pastorpreneur or entrepreneurial pastor teaches the members to pray and to ask God to guide and lead them as they work in these depressing township communities. It is true that this was working in these communities even before the church existed. And God has a better plan for every community. By prayer, people seek that plan of God.

Entrepreneuring is all about the grand narrative of emancipation, by breaking free from the power of another and by breaking free from the existing social order, inherently linked with the status quo (Haugh \& Talwar 2016). Once the people who have been marginalised step up into social entrepreneurship spirit, the dependency spirit falls off their lives. True freedom begins when the excluded claim their rightful place in the world. Townships, being places on the outskirts of the cities, are the historical locations for marginalisation and exclusion of the black South African people from participating in the economy of the country and the township economy.

Local people continued saying it is hard for them because when they speak, they are labelled as xenophobic. Other local people said black South African people should stop complaining like children and begin to realise this is business. They should begin to be innovative so that they might be competitive in running their businesses.

\section{Holistic community transformation}

The word 'transformation' means changed in form, transfigured and transformed into another form or structure (Manyaka 2010:109). The process can be radical or thorough, or a dramatic change in form, outward appearance and character. Transformation of a township means that the townships become likeable and liveable places to live in.

According to Oxford Advanced Learner's Dictionary, 7th edition, 'holistic' means, 'considering the whole thing or being to be more than a collection of parts'. So, holistic community transformation refers to the interaction of the parts of the whole. To understand the whole, one must understand the parts and their roles in relation to the whole. The following could be considered as components of a holistic community transformation: human spirit, psychological, physical emotional, social, economic and political.

The process of transformation should start with the mindset; as it has been said, processes of change cannot be effective without deep-rooted personal transformation, which could be the catalyst that will ignite the search for new ways of doing things (Edwards \& Sen 2000:610). Transformed minds will start to live a productive life. They are no longer only consumers, but they are producers. They will get involved in community projects to change their own lives and lives of others (Manyaka 2010:111).

The Bible also stresses the importance of the mind in Proverbs 23:7; it says, 'for as the man thinks in his heart, so is he'. It teaches us that whatever we focus our mind on, it might happen. If people in the township keep thinking about poverty, it will cloud their thoughts and all they will see is the poverty without any solution to reduce the poverty. It would be helpful if people in the township would realise that they have been created in the image of God as stated in Genesis 1:26. This will bring a sense of significance in their lives and possibilities of imagining transformation will grow that will lead them to act appropriately. 
Transformed thinking will lead to social transformation. Groenwald (2000) (in Erasmus 2005) defines social transformation as:

... to transform is to change in form or appearance; in condition, nature or character. The social is concerned with human beings in their relations to each other, their living condition, and living together in organized communities. (p. 140)

Community transformation should affect every sphere of the human being. Wint and Ngcobo (2000:93) stated that transformation in South Africa is all about moving from exclusion into inclusion in the spheres of life, such as economic, political and social, and that all people are able to share in all of the opportunities that are in the country.

Holistic community transformation aims at touching all spheres of life. It causes a total shift in the way we think and act. It shifts the way we relate with our fellow men and women.

\section{Empowerment and missional social entrepreneurial church}

The above community transformation cannot be realised without the empowerment of the community members. Empowerment is a role of the missional social entrepreneurial church. What is empowerment? Manyaka (2010:122) defined it as 'empowering to give someone authority to do something'. So empowerment could be defined as a process of giving someone authority to do something.

Kim et al. (2007:39) have defined empowerment as the process of increasing the capacity of individuals or groups to make choices and to transform those choices into desired actions and outcomes.

\section{Von Kotze (2007) stated that:}

empowerment is the capacity to perform the actions necessary to create and sustain life, including being able to identify and make use of livelihood opportunities and cope with stress and shocks. (p. 235)

According to Ahmed and Abu Talib (2016:1041), empowerment is defined as 'any process by which people's control (collective or individual) over their lives [is] increased'.

Therefore, to conclude, community empowerment can be achieved through community participation, capacity building and access to appropriate information (Ahmed \& Abu Talib 2016).

All the theories of empowerment agree that community empowerment is a process. What is a process? According to the Oxford Advanced Learner's Dictionary, 'process' means 'a series of things that are done in order to achieve particular results'. Also it could mean the method of doing or making something. The process of empowerment could be as follows:

- Participation: Every empowerment must start with inviting the community members to a needed project.
The members must be part of project identification. It means that community members must take full ownership of an identified project. It is not imposed by developers who are not part of a community.

- Capacity building: After community members have fully participated in the project, building community members' capacity becomes a critical need. Capacity building means the up-skilling of members so that they can exercise their agency. It will help them to fulfil their role in the project. This will give them control of their lives and their responsibilities.

- Access to information: Relevant information on whom to contact and where to get necessary resources is extremely important. Information on financials and funding is critically essential in making choices and putting all of these choices into action and outcomes. The information will empower the community members to act appropriately in all series of happenings.

- Accountability: It refers to the ability of the poor community members to call public officials, private employers or service providers to account. Officials and private employers must be aware that they serve the poor people and they must be aware that poor people are coproducers and they are in partnership with them.

- Local organisations capacity: It is a process that enables people to work together, organise themselves and mobilise resources to solve their problems of common interest.

\section{Practical theology}

Browning (1996:9) argues that 'we should move in theology from practice to theory and back to practice'. He stressed that is how humans operate. It is impossible to start from theory to practice. As we live, we encounter a problem or a challenge and begin to think or reflect about the challenge.

Park (2010) mentioned significant characteristics of practical theology, which are transformational, contextual and situational, experiential, interrogative, interdisciplinary, analytical and dialectical and disciplined. Tracey (1983:76) argues that 'practical theology is the mutually critical correlation of the interpreted theory and praxis of the contemporary situation'.

Manyaka (2015:6) and Muller (2005:77) argue that postfoundationalist practical theology happens whenever and wherever there is a reflection on practice, from the perspective of God's presence: 'it can be very spontaneous, informal, and local'. Postfoundationalist practical theology is always happening in that moment of practice. It is not imposed on the context but is born in the context as it gives the sources to reflect upon.

Muller (2011:3) added that 'the postfoundationalist practical theology approach forces us to first listen to the stories of people struggling in real life situations, to bring forth pastoral concerns to reflect on'. 
In this article, the author suggests that the narratives of people who live in the township communities should be critically listened to. According to Statistics South Africa, more than half of the population is out of work (Manyaka 2015:1). In its quarterly Labour Force Surveys for JanuaryMarch 2016, Statistics South Africa announced that 5.2 million people, or $26.7 \%$ of the population, were unemployed (Stats SA 2016). The narratives of God's presence in their situation should be listened to. Even though the article proposes social entrepreneurship as one possible solution to fight poverty and something that can give people freedom, it cannot be imposed upon their lives as a solution for them. The preferred future or solution should be born out of the local specific context. The theology must be born in the local context.

The article recommends that a social entrepreneurial pastor has to gather relevant stakeholders in his or her church and community to reflect on what is happening in the community and shape the way forward for their community. This is a postfoundationalist practical theological approach in addressing the concerns that are found in the local specific context. The following would assist those who work inside township communities to be agents of community transformation.

Muller (2011:3) spells out the foci of a holistic pastoral ministry in the context of poverty:

- Real concern about real people. Concerns in this paradigm are never theological, but always local and embodied.

- Not a knowing approach, but rather one of active engagement.

- An interdisciplinary approach, not on the basis of assimilation, but on the basis of transversal rationality.

- A holistic perspective, in the sense of being fully committed to the real contextual story and committed to exploring traditions of interpretation.

- A social-constructionist approach, where a person is part of the development of a preferred reality that makes sense to him or her. Such an approach creates both the most profound and the most fragile moments: a moment of true pastoral concern:

Therefore, a practical theologian will invite social workers, teachers, nurses, engineers, etc. who are members of the church to reflect on social entrepreneurship and how to empower the community to start their own business or how to promote entrepreneurial activities in the townships. In this process, community members are not merely spectators; they own the process. (Manyaka-Boshielo 2017a:8)

Missional social entrepreneurial church fits well with this inclusive approach of different disciplines promoted by postfoundationalist practical theology. The author believes that when the township community members can work together, nothing will be impossible for them to achieve.

The township communities should be made aware that they have what it takes to construct the world they wish to live in.
This construction of preferred reality is in their power to make happen.

\section{Implementing successful social enterprise}

The purpose of the missional social entrepreneurial church is to create a social value. The church encourages and empowers its members and community members to actively engage in establishing social enterprises that will continue creating social values in township communities.

The author suggests the following that would assist to establish a successful social enterprise.

\section{Restoring human identity}

The researcher heard the frustration expressed by the people of Nellmapius, especially those who are trying to earn a living. They have lost self-confidence, self-worth, etc. They describe themselves as failures (Manyaka-Boshielo 2017:5a). The identity of the Nellmapius community is broken because of living in poverty:

Because of the conditions people live under, it crushed their thinking capacity and they end up thinking that life is not worth living and they cannot achieve anything in life. (ManyakaBoshielo 2017:5a)

Entrepreneurial pastors are to preach and teach the love of God to these community members. They should be reminded that they have been created in the image and likeness of God (Gn 1:26). And they have got what it takes to make it in life. The township communities should be aware that great potential is deep within them. As Munroe (1998) put it:

third world people must look for the inner strength and potential lying deep within them. With a renewed commitment to the Creator, Jesus Christ, they must prepare themselves to refine their skills. (p. 84)

These people would begin to accept themselves as people who are equal to the non-poor people.

\section{Interrelationship}

The township communities should be made aware that they need other community members to succeed in their social enterprise.

The third element of power is 'power with'; this covers the communal dimensions, such as group solidarity or collective action, which acknowledges that a positive change may often be effected through acting together rather than alone (Kim et al. 2007:28).

To establish a successful social enterprise would take township community members, government and private sector together to develop and to be sustainable. So, to learn about people skills will be necessary. The courses on how we can better relate with others are critically needed. 


\section{Relevant skills}

There are three sets of skills that are needed to be successful in establishing social enterprise: cognitive skills, technical skills and people skills (Manyaka 2015:3). With high unemployment and poverty in township communities, a missional social entrepreneurial church must encourage the community members to acquire some skills so that they would be able create their own employment through enterprise in their communities. The following would be a few of those skills that might be needed to start:

- ability of seeing opportunity and acting on it

- ability of doing feasibility study

- the writing of a business plan

- putting healthy management systems

- ability of marketing of the product or service.

\section{Establishing social enterprise in Township}

Unemployment and poverty can be addressed through establishing social enterprises in townships. The following would be a process of establishing a successful social enterprise in township communities.

According to Dees (1998), 'social and business entrepreneurs recognise and relentlessly pursue opportunities for the creation of (social) value'. This recognition of opportunity happens in an unjust equilibrium that causes marginalisation and exclusivity of the poor people. The social entrepreneurs have the ability to look beyond the current situation and see how things should be. In simple terms, entrepreneurs define the problem in their community well. After they have clearly understood the problem, they define the possible solutions to the current problem. Then they will define how they will solve the problem. The strategy will guide them to what needs to be done.

Kaplan and Warren (2007) list five phases that must be negotiated successfully by the entrepreneur:

- Phase 1: Seize the opportunity. Social entrepreneurs operating in the township communities should not waste time when the opportunity arises.

- Phase 2: Investigate the need through market research. The research will assist the social entrepreneurs to see if the opportunity they have recognised is feasible or doable or not.

- Phase 3: Develop a plan. If the opportunity is feasible, then the social entrepreneur will draw up a plan for execution. The plan is a guiding map of the social entrepreneur in the township.

- Phase 4: Determine the resources needed. After the plan has shown what is needed, the social entrepreneur will assess it and organise the necessary resources that are required.

- Phase 5: Manage the business. The entrepreneur should learn about managerial skills to manage his or her business. It takes relevant skills to make a business successful.

\section{Empowerment workshops}

As the missional social entrepreneurial church believes in an interdisciplinary approach to community ministry, after interdisciplinary discussion workshops would be arranged for the community. The workshops should focus on what has been decided upon as the opportunity.

The author thinks that the first workshop should be on personal empowerment. This workshop should be more on recovering the human identity that has been destroyed by poverty. The second workshop should focus on human relations or what might be known as people skills. The third workshop should be more on leadership and managerial skills. These workshops could be turned into the programme that will be offered to the township community. By doing so, the church will begin to be the light and the salt of the township community. This is the church that will be able to self-govern, self-support and self-sustain.

\section{Missional social entrepreneurial church as an incubator}

Manyaka (2015:3) argues that incubators help the entrepreneur's new venture to overcome the liabilities of 'newness', particularly the lack of role models, standardised communication channels, trust and credibility and established clientele (Bull \& Willard 1993:189).

\section{Role models}

As a new business, one needs to learn from established businesses. The new entrepreneur will learn from the mistakes of those who have experience in businesses so that he or she will not repeat them. It would be lovely for the township businesspeople to collaborate with big business so that they could learn from them. In this article, the missional social entrepreneurial church will act as the incubator by working with different business companies. These companies will be coming to the hub run by the church to collaborate. The learning will take place during the interactions.

\section{Standardised communication channels}

The new entrepreneur might not have an effective communication system because of the lack of money and newness. The entrepreneur will use the communication system of the big business. According to this article, the church through the business hub created will empower social and business entrepreneurs.

\section{Trust and credibility}

Big businesses as incubators will absorb the lack of trust and lack of credibility from new entrepreneurs. The big businesses will cover the new businesses at all costs. The venture would be exposed to the market, and the market will begin to know the small venture. 


\section{Established clientele}

As a new venture, there are no clients whom you know. So to be under the umbrella of a well-established business will expose a new venture to the clientele of the established business. This is one of the benefits that new ventures can receive when they operate in business incubation.

This kind of church will be able to facilitate networking among the small businesses in the township community, where the spirit of not trusting each other is prevailing. This would be the environment that will allow the small businesses to market their business and to link up with big businesses that operate in a big way in the world. This will encourage the sharing of resources among the small businesses in the township communities. In fact, the big businesses operating in township communities must be forced to consider partnering with a small local businesses as a way of skills transfer and community empowerment.

\section{Conclusion}

At the end of this journey, indeed, the missional social entrepreneurial church could be the light and the salt. The church is not just to prepare people to go to heaven but to assist people in acquiring life skills. The promotion of entrepreneurial skills helps the church members and community at large to know how to catch the fish rather than to give them one.

Social entrepreneurship is about social value and the entrepreneurial activities are about raising money to support the social mission of the social entrepreneur. As the township community members develop entrepreneurial activities, they begin to be free from the oppression of thinking that they cannot make it by themselves.

The practical theological approach is enriching the participation of those who are historically marginalised and excluded to take ownership of constructing the preferred reality that would move them forward in the community and economic transformation.

\section{Acknowledgements Competing interests}

The author declares that he has no financial or personal relationships which may have inappropriately influenced him in writing this article.

\section{References}

Ahmed, M.S. \& Abu Talib, N.B., 2016, 'Analysis of community empowerment on projects sustainability: Moderating role of sense community', Social Indicators Research 129, 1039-1056. https://doi.org/10.1007/s//205-014-0781-9

Austin, J., Stevenson, H. \& Wei-Skillern, J., 2006, 'Social and commercial entrepreneurship: Same, different or both?', Entrepreneurship Theory and Practice 30(1), 1-22. https://doi.org/10.1111/j.1540-6520.2006.00107.x

Bornstein, D., 1998, 'Changing the world on shoestring', Atlantic Monthly 280(1), 34-39.

Browning, D.S., 1996, A fundamental practical theology, descriptive and strategic proposal, Fortress, Minneapolis, MN.
Bull, I. \& Willard, G.E., 1993, 'Towards a theory of entrepreneurship', Journal of Business Venturing 8(3), 183-195. https://doi.org/10.1016/0883-9026(93)90026-2

Buttrick, G., 1962, The interpreter's dictionary of the Bible, Abingdon, Nashville, TN.

Carlson, R., 2007, Definition of missional church, missional church strategist for national ministries, American Baptist Churches.

Charman, J.E., Petersen, L.M., Piper, L.E., Liedeman, R. \& Legg, T., 2017, 'Small area census approach to measure the township informal economy in South Africa' Journal of Mixed Methods Research 11(1), 36-58. https://doi.org/10.1177/ 1558689815572024

Choi, H., 2010, 'Institutions and ethnic entrepreneurship: Koreans Ethnic church as incubator of economic', Development Quarterly 24(4), 372-381. https://doi. org./10.1177/08912410375426

Choi, H., 2017, 'Missional conversion and transformation in the context of Korean protestant church', The Journal Mission Studies 34, 53-77. https//doi. org/10.1163/15733831-1234183

Dees, J.G., 1998, The meaning of 'social entrepreneurship', draft report for the Kauffman Center for Entrepreneurial Leadership, Stanford Úniversity, Stanford, CA.

Dodd, S. \& Seaman, P.T., 1998, 'Religion and enterprise: An introductory exploration' Entrepreneurship: Theory and Practice 23, 71-86. https://doi. org/10.1177/104225879802300104

Edwards, M. \& Sen, G., 2000, 'Ngo's, social change and the transformation of human relationships: A 21st -century civil agenda', Third World Quarterly 21(4), 605-616. https://doi.org/10.1080/713701069

Erasmus, J.C., 2005, 'Religion and social transformation: A case study from South Africa', Transformation 22(3), 139-148. https://doi.org/10.1177/026537880 502200303

Gonzalez, J., 1984, The Early Church to the dawn of the reformation, Harper and Row, San Francisco, CA

Haugh, H.M. \& Talwar, A., 2016, 'Linking social entrepreneurship and social change: The mediating role of empowerment', Journal of Business Ethics 133, 643-658. $\mathrm{https}$ ://doi.org/10.1007s10551-014-2449-4

Kaplan, J.M. \& Warren, A.C., 2007, Patterns of entrepreneurship management, 6th edn., Wiley, Hoboken, NJ.

Kim, J.C., Watts, C.H., Hargreaves, J.R., Ndlovu, L.X., Phetla, G. \& Morrison, L.A., 2007, Understanding the impact of a microfinance intervention on women's empowerment and reduction of intimate partner violence in South Africa', American Journal of Public Health 97(10), 1794-1802. https://doi.org/10.2105/ AJPH.2006.095521

Manyaka, S.J., 2010, 'The marginalized stories of people who live in poverty: A pastoral narrative approach to community transformational development', Unpublished PhD thesis, University of Pretoria, Pretoria.

Manyaka, S.J., 2015, 'Social entrepreneurship: A solution for transforming the disadvantaged community of Nellmapius', HTS Teologiese Studies/Theological Studies 71(3), Art.2821, 7. https://doi.org/10.4102/hts.V71i3.2821

Manyaka-Boshielo, S.J., 2017a, 'Social entrepreneurship as a way of developing sustainable township economies', HTS Teologiese Studies/Theological Studies 73(4), a3830. https://doi.org/10.4102/hts.v73/4.3830

Manyaka-Boshielo, S.J., 2017b, 'Exploring possibilities of Social entrepreneurial activities as a tool to reduce unemployment amongst churches in Tshwane central and Mamelodi east: Pretoria case study', HTS Teologiese Studies/Theological Studies 73(3), 7. https://doi.org/4102/hts.u73i3.4706

Martin, R.L. \& Osberg, S., 2007, Social entrepreneurship: The case for definition Stanford Social innovation Review.

Muller, J.C., 2005, 'Postfoundationalist, HIV-Positive practical theology', Practical Theology in South Africa 20(2), 72-88.

Muller, J.C., 2011, 'Postfoundational practical theology for time of transition', HTS Teologiese Studies/Theological Studies 67(1), Art 837, 5. https://doi.org/10.4102/ hts.v67i1.837

Munroe, M., 1998, Seasons of change: Understanding purpose in times of perplexity, Pneuma Life, Lanham, MD.

Park, S.K., 2010, 'Post foundational research paradigm of practical theology', HTS Teologiese Studies/Theological Studies 66(2), Art \#849, 6. https://doi.org/10. 4102/hts

Pippin, A., 2001, 5 Secrets of the authentic entrepreneur, viewed 17 December 2017, from http://www.businessstoolchest.com/articles/data/20010124151220.shtml

Rahim, H.I. \& Mohtar, S., 2015, 'Social entrepreneurship: A different perspective', International Academic Research Journal of Business and Technology 1(1), 9-15.

Rey-Marti, A., Rebeiro, D. \& Palacios-Mangues, D., 2016, 'A bibliomatrics analysis of social entrepreneurship', Journal of Business 6, 1651-1655.

Statistics South Africa (Stats SA), 2016, Quarterly Labour Force Survey (OLFS) 1st Quarter 2016, viewed 20 June 2016, from http://www.statisticssa.gov.za/ publications/PO211/PO2111stQuarte2016.pdf

Tracey, D., 1983, 'The foundations of practical theology', in D.S. Browning (ed.), Practical theology: The emerging field in theology, church, and world, pp. 61-82, Harper \& Row, San Francisco, CA.

Van Gelder, C., 2000, A essence of the church: A community created by the Spirit, :Bakers Book House, Grand Rapids, MI.

Von Kotze, A., 2007, 'Poverty, work and education', Convergence 40(3-4), 231-237.

Wint, E. \& Ngcobo, T., 2000, 'We don't have to go to bed on phuthu alone: A case of transformation in Colenso', Journal of Social Development in Africa 15(2), 93-114. https://doi.org/10.4314/jsda.v15i2.23861

Woodward, J.R., 2012, Creating a missional culture: Equipping the church for the sake of the world, IVP Press, Madison, WI. 